\title{
THE PRACTICE OF RATING COVERED BONDS
}

\author{
Katalin Mérö
}

\begin{abstract}
This article analyses and compares the rating of covered bonds in the practice of the five credit rating companies which have 90\% market coverage in the rating of European covered bonds (Moody's, S\&P, Fitch, DBRS and Scope). The rating of covered bonds tends to be excellent, it can even be significantly better than that of the issuing bank or that of the country in which the bank is located. The main reason for this are the different lines of defence laid down in regulation, which are also supported by the large-scale covered bond purchasing programme of the European Central Bank on the market's side. The question is whether these lines of defence can really be deployed with full effectiveness in the event of significant turbulence in the real property market or a systemic banking crisis or a sovereign crisis, i.e. whether the current practice of the rating of covered bonds is not too optimistic.
\end{abstract}

JEL codes: G21, G23, G28

Keywords: covered bonds, credit rating agencies

\section{INTRODUCTION}

Professional literature often attributes the American subprime crisis and the 2008 global financial crisis resulting from the subprime crisis to credit rating agencies (White, 2009, Mullard, 2012, Scalet-Kelly, 2012). In the years before the crisis, credit rating agencies gave structured bonds (so-called CDOs²), which were issued in increasing volume, derived from high-risk retail mortgage loan portfolios and carried complicated risks, excellent rating, on the basis of which investors might have thought that these bonds carried minimal risk. When American real estate prices started decreasing, these bonds with excellent rating became very risky or often defaulting one after another, due to the deterioration of the underlying loan portfolio. Credit rating agencies took action only after this process had already finished, i.e. they downgraded the rating of CDOs by several categories

\footnotetext{
1 Katalin Mérő, Associate Professor, Budapest Business School. E-mail: Mero.Katalin@uni-bge.hu.

2 CDO: Collaterized Debt Obligation.
} 
suddenly. A large number of CDOs which had had AAA or AA ratings earlier were suddenly reclassified into one of the speculative categories. On the one hand, credit rating agencies really belonged to those who were responsible for the crisis, on the other hand, they undermined investors' confidence in ratings.

After the crisis, the previously completely unregulated, market-based credit rating agencies became regulated and supervised institutions. In the European Union, the activity of credit rating agencies is regulated by a regulation and a directive $^{3}$, while they are supervised by the European Securities and Markets Authority (ESMA). The objectives of the regulation include the improvement of the quality of ratings, making the methodology of credit rating agencies transparent and increasing their accountability related to the issued ratings. In view of the above, we might think that credit rating is a very reliable method that really helps us make proper judgement about the riskiness of investments, even in terms of bonds issues the riskiness of which is relatively complicated for non-professionals.

In this article, we analyse whether, in the case of a special product group, the covered bonds, which belong to structured finance products, the following statement is true: the rating of such products reflects the risks of the underlying products well and, as a result, appropriately orientates investors. In fact, covered bonds are loan portfolios packed, issued and sold in the form of bonds by banks. The original loans remain in the books of the bank. The loans covering the bonds are separated from other instruments in the registry, as such loans and the underlying collaterals serve as special guarantees for bondholders. Covered bonds are typically issued to securitise retail mortgage loans and loans granted to the public sector. Basically, covered bonds differ from CDOs which were wide-spread prior to the global financial crisis. The only similarity between them is that both bond types are covered by mortgage loans. However, covered bonds are simpler than CDOs and carry more transparent risks, as in their case, the loans and the underlying collaterals are not separated. In addition, the structural characteristic described in next part of the article (dual recourse, overcollateralization) and regulatory protection also contribute to the fact that covered bonds belong to lowrisk financial instruments, as opposed to high-risk CDOs or even unsecured bank bonds.

In our analysis, we focus only on the covered bonds issued by the member states of the European Union. As the EU's (more or less) uniform regulatory system applies only to such bonds, they can be treated as a relatively homogeneous product group. In our analysis, we do not set up our own risk assessment model, which could be compared with the models of credit rating agencies. Instead, we follow,

3 Regulation No 462/2013 and Directive 2013/14/EU. 
compare and assess the rating processes and the methodological steps applied by the three market-leading credit rating agencies (Moody's, Standard and Poor and Fitch), as well as by the next two largest European credit rating agencies (DBRS Ratings and Scope Ratings) which deal with the rating of structured products, but can be rather classified into the category of smaller rating agencies.

The practice of rating covered bonds is especially interesting, as prior to 2008 , practically only covered bonds with AAA rating (belonging to the best rating category) were in the market. After 2008, there were also covered bonds with worse ratings, but bonds with excellent rating (at least As) have typically belonged to this category to date.

Our article has the following structure: Following the introduction, we provide a brief summary of the European covered bond market, then we summarise the regulatory aspects which are of crucial importance regarding the riskiness of covered bonds and the relevant ratings. In the following part, we compare and analyse the covered bond rating practices of the five credit rating agencies. At the end of the article, we draw some conclusions.

\section{THE MARKET OF COVERED BONDS IN THE EU}

The covered bond market is typically a European market. Its development started in some countries outside Europe only a few years ago. In several European countries, it is a traditional and generally wide-spread form of refinancing retail mortgage loans that lending banks issue mortgage bonds. The financed real properties serve as the collateral for bonds, therefore mortgage bonds are considered to be safe bond (with low interest rates) in capital markets. Banks can refinance loans granted to the public sector by issuing a bond facility that is the same as mortgage bonds. In some countries, even ships can be financed in this manner (ECBC 2020). Such bonds are jointly referred to as covered bonds. The main characteristic of covered bonds is the so-called dual recourse, i.e. the issuing bank shall act as a guarantor for payments related to the bonds, but in the event of the incidental bankruptcy of the bank, bondholders shall be paid firs from the underlying collaterals. As long as this is not the case, the collaterals shall not be used for any other purposes. Another feature of covered bonds is that the value of the underlying collaterals is higher than the issue price of the bonds. This kind of overcollateralization is needed to keep the value of the underlying collaterals of bonds at appropriate level even if real property prices drop. A separate regulatory system, which is introduced in the following part of the article, applies to the financing of covered bonds. 
Covered bonds play an important role in European bond markets. In 2015, the stock of covered bonds (EUR 2.1 billion) exceeded the total stock of bonds issued by non-financial enterprises (EUR 1.8 billion) by $17 \%$ (Kemmish et al., 2017). The European covered bond market is highly concentrated. The four largest issuing countries provide $64 \%$ of the total European covered bond stock (Table 1 ). The reason for differences between countries is that the weight of financing with covered bonds differs within retail mortgage lending in each country. In Denmark, retail mortgage lending is financed exclusively with covered bonds. This rate is $40-60 \%$ in Sweden, Finland and Italy, approximately $40 \%$ in Portugal and Spain, around $20 \%$ in Germany, while between $\mathbf{1 5 - 2 0 \%}$ in France and the Netherlands (Stöcker, 2020). In the 2010s, the stock of bonds issued for the refinancing of loans granted to the public sector was continuously decreasing, while the stock of bonds issued for the refinancing of mortgage loans significantly increased (Table 2).

The issue of covered bonds is also supported by the fact that the European Central Bank (ECB) conducts considerable covered bond purchases in the framework of its asset purchase programme, as well. The first asset purchase programme of the ECB was launched in July 2009. In a year's time, the ECB purchased covered bonds worth EUR 60 billion, which it intends to keep in its portfolio until maturity. The second covered bond purchase programme between November 2011 and October 2012 was worth EUR 16.4 billion, and the purchased bonds were also to be kept until maturity. The third covered bond purchase programme of the ECB lasted from October 2014 to December 2018. Since January 2019, the ECB has reinvested amounts from the repayment of matured bonds in covered bonds. In the framework of the third bond purchase programme, the ECB has been buying covered bonds again since 2019, and not only to substitute the matured ones, but with the aim of continuously expanding its portfolio. In February 2021, the value of the total stock of bonds purchased in the framework of the third covered bond purchase programme amounted to EUR 289 billion. ${ }^{4}$

4 https://www.ecb.europa.eu/mopo/implement/app/html/index.en.html. 
Table 1

The stock of covered bonds in the EU and outside the EU (2019, EUR billion)

\begin{tabular}{lc}
\hline In the EU, in total: & 2128.8 \\
\hline The largest: & \\
Denmark & 419.4 \\
Germany & 364.1 \\
France & 334.2 \\
Spain & 241.5 \\
Countries outside the EU & 576.7 \\
\hline In total: & $\mathbf{2 7 0 5 . 5}$ \\
\hline
\end{tabular}

Note: The United Kingdom is already listed among countries outside the EU in the table.

Source: ECBC (2020):

Table 2

The global stock of covered bonds by underlying loan type (2010-2019, EUR billion)

\begin{tabular}{lcccccccccc}
\hline & 2010 & 2011 & 2012 & 2013 & 2014 & 2015 & 2016 & 2017 & 2018 & 2019 \\
\hline Public sector & 653.0 & 616.5 & 544.0 & 464.8 & 408.6 & 371.5 & 335.5 & 312.5 & 294.0 & 282.7 \\
Mortgage & 1836.4 & 2041.6 & 2245.4 & 2131.2 & 2088.5 & 2116.1 & 2146.5 & 2140.3 & 2275.8 & 2414.0 \\
\hline
\end{tabular}

Source: ECBC (2020):

In the future, covered bond issue is expected to have a more significant role, as it is an important pillar of the 2015 action plan for the establishment of the Capital Markets Union (European Commission 2015) and the provision of liquidity along with the purchase of covered bonds has been constantly playing a key role in the toolkit of the European Central Bank. 


\section{THE REGULATION OF COVERED BONDS AND CREDIT RATING AGENCIES IN THE EU}

\subsection{The regulation of covered bonds}

In the EU, the comprehensive and detailed regulation of covered bonds took place within the framework of the action plan for the establishment of the Capital Markets Union in 2019, by adopting a directive on covered bonds 5 . The aforementioned directive has to be implemented by the member states by July 2021 and applied by July 2022 at the latest. A detailed analysis of the new regulation can be found in Stöcker (2021). Consistent with reason, the credit rating practices analysed in this article were still developed in accordance with the previous regulation. On the whole, it can be stated that covered bonds are rather pushed by the new regulation into a less risky direction, i.e. we do not expect a stricter rating practice in the future than the one introduced in this article.

Until the adoption of the 2019 regulation on covered bonds, covered bonds had not been legally defined in the European Union. In practice, the so-called UCITS Directive contained a definition ${ }^{6}$. The directive aimed to specify the covered bonds from which UCITS-compliant investment funds could have a higher percentage in their portfolios than allowed by the general regulation. As a general rule, securities from a given issuer can make up max. $5 \%$ of the portfolio of an investment fund, while, in the case of covered bonds complying with the definition of the UCITS, this limit was set at $25 \%$. In other words, the regulation declared that the risk of covered bonds fulfilling the requirements of the definition was extremely low. Although it was a special purpose definition, in the absence of another definition, it was used and considered as the standard in the EU. In accordance with the UCITS regulation, covered bonds recognised by the regulation shall meet the following criteria in the EU:

- Within the EU, such covered bonds shall be issued by a bank registered in the EU;

- special state prudential supervision and state supervision protecting bondholders shall apply to the issuers of the bonds;

- during the whole lifetime of the covered bonds, the underlying assets shall serve as appropriate collaterals for the bondholders; and

5 Directive (EU) 2019/2162

6 Directive 2009/65/EC Article 52 
- in the event of the bankruptcy of the issuing bank, the claims of the bondholders shall take priority (dual recourse principle).

The EU's regulatory system allocates several additional benefits to the covered bonds defined above, as well. Regarding banks, it is an important factor that the regulation on the calculation of capital requirements allocates favourable risk weighting to covered bonds ${ }^{7}$, and covered bonds can be considered as liquid assets when calculating the Liquidity Coverage Ratio ${ }^{8}$. On the other hand, it is a serious advantage for investors that covered bonds cannot be involved in the crisis management process in the course of the resolution procedure of banks (they are not part of the "bail-in")9. The European Central Bank accepts covered bonds which comply with the UCITS definition as collateral for repo deals, and can buy them in the framework of its asset purchase programme if their ratings are BBB- or higher. In 2016, the European Banking Authority examined the regulatory practice of covered bonds in the EU member states (EBA 2016) and compared it with the eight principles of regulatory practice which the European Banking Authority recommended earlier (EBA 2014). The EBA concluded that the regulation of covered bonds was very different in the member states. The survey included $21 \mathrm{EU}$ member states which had their own national regulation on covered bonds. The only principle with which the regulation of all the 21 countries complied was the principle of dual recourse. Namely, all countries appropriately stipulated that, despite the fact that the claims embodied by the covered bonds exist against the issuing banks, in the event of the banks' insolvency, the investors' claim with the cover pool still exist. In other words, the cover pool cannot be allocated for any other purposes. Furthermore, national regulatory practices are very similar in the following respect: banks separate underlying assets even legally from their other assets, so that, in the event of the bankruptcy of the issuer, the bondholders still receive the payments under the original terms and conditions and revenues from the underlying assets cover not only the capital and interest payment obligation related to the bonds themselves, but also all other potential payments related to the covered bonds (including operating expenses, as well). Only a (in some areas a smaller) part of the national regulatory practices complies with the other principles of best regulatory practices. For example, this category includes principles of liquidity, disclosure, stress testing and supervisory regulation.

7 CRR Article 129

8 Commission Delegated Regulation (EU) 2015/61, Articles 11,12 and 13.

Directive 2014/59/EU Article 44. 


\subsection{The regulation of credit rating agencies}

In the European Union, the regulation of credit rating agencies started immediately after 2008, only taking into account the lessons learnt from the flaws of the rating system of structured products at the time. In 2013, the regulation was considerably extended, incorporating the lessons learnt from the mistakes committed by rating agencies during the European sovereign crises (Gaillard, 2013) into the regulation. The EU adopted a regulation and a directive to regulate credit rating agencies ${ }^{10}$, while the European Securities and Markets Authority (ESMA), which was set up in 2010, was appointed to authorise, register and supervise them. Originally, the regulation was intended to lay down the criteria the credit rating agencies had to meet so that different financial institutions could use their rating for prudential calculations. However, the final regulation was much more ambitious, as in general, it applies to rating activity, irrespective of the aim of usage.

The regulation contains detailed rules on the methodologies and models to be applied by credit rating agencies, as well as on their underlying considerations. ${ }^{11}$ Based on these rules, when making a decision on the rating, credit rating agencies have to consider all available information that is relevant. The rating methodology has to be strict and based on previous experience, including the subsequent back-testing of the applied models. The methodology of ratings has to be continuously maintained and reviewed at least once a year.

In addition to general provisions, the requirement of dual rating of structured financial instruments also applies to the rating of covered bonds. In other words, these complicated bonds with hardly transparent risks have to be rated by two independent credit rating agencies. Moreover, the regulation strongly suggests that in such a case, one of the credit rating agencies should be an agency with a market share under $10 \%$ in the entire rating market. In practice, it means that covered bonds have to be rated by at least one rating agency that does not belong to the three largest credit rating agencies. In order to ensure the compliance of the methodologies, the regulation prescribes several organisational, operational and personal conditions, rules on the presentation of the information and methods used for making a decision on the ratings, as well as disclosure requirements.

In accordance with the regulation, the methodology that credit rating agencies apply to the rating of covered bonds is publicly available, therefore, in the next part of our article, we compare the methodologies used by the five largest credit rating agencies in the market of structured products.

\footnotetext{
10 Regulation 462/2013, Directive 2013/14/EU.

11 The aforementioned rules are specified in Article 8 of the regulation.
} 


\section{THE RATING OF COVERED BONDS IN THE PRACTICE OF CREDIT RATING AGENCIES}

\subsection{Generally applied principles}

Covered bonds are issued by banks, therefore when it comes to their rating, the starting point at each credit rating agency is the credit rating of the bank issuing the bond. At the same time, due to the regulation on covered bonds, it is always true that such bonds carry lower risks than other uncovered bonds issued by the issuing bank. The holders of covered bonds often have access to their receivables represented by the bond even after the contingent failure of the issuing bank. Namely, if the bank, as an issuer, stops the payments related to the bonds, the elements integrated in the regulatory construction of the bonds enable the maintenance of the continuity of the payments related to the bonds. Each rating agency rewards this by giving the bond a better rating than that given to the issuing bank by using their methodology developed for this purpose. Each methodology has the following structure: they define the factors which could justify upgrading on the rating scale, then they quantify by how many rating units (so-called notches) they improve the rating of the bond concerned due to the existence of the given factor. The extra notches along the factors which justify improvement are added, and the rating of the initial bank is improved by this score. The rating of the covered bond can either be the same as the rating calculated in this way, or, if the rating has reached its upper limit (if it exists), the covered bond receives the rating that corresponds to this upper limit. The upper limit is typically related to the sovereign rating of the country in which is issuing bank's seat is located, but it is significantly better. Possible upward diversion tends to be very generous (typically by six notches), which means that a covered bond issued by a bank from a country with an A- rating for Treasury bonds issued in domestic currency may receive AAA rating on the scale of $S \& P$ or Fitch.

Deduced from the regulation, credit rating agencies usually improve the rating of covered bonds compared to the rating of uncovered bonds issued by banks for the following reasons:

- based on the dual recourse principle, in the event of contingent bankruptcy, the underlying collateral of the bonds is separated from other assets and can only be used for satisfying the claims of the holders of the covered bonds

- in the event of the bank's resolution, covered bonds can be extracted from bail-in 
- the quality of the cover pool, which refers not only to the modelling of the probability of default and return (expected loss-based modelling), but also to overcollateralization $^{12}$.

- Various liquidity support systems which enter into force in the event of the bankruptcy of the issuing bank and enable the payment of the covered bonds in time.

For the above reasons, rating given by credit rating agencies to covered bonds can be higher even by 9-13 notches than the rating given to the uncovered bonds of the same bank. For example, by using the rating scales of S\&P or Fitch ${ }^{13}$, having regard to the general practice of credit rating agencies, credit rating agencies classify bonds with at least $\mathrm{BBB}$ - rating into the investment grade category, while bonds with worse, $\mathrm{BB}+$ or under $\mathrm{BB}+$ rating are classified into the speculative or junk categories. The difference between $\mathrm{BB}+$, which represents the top of the junk category, and the practically risk-free AAA category is 10 notches. In other words, the rating of a bond issued by a bank from the junk category or the bottom of the investment grade category may easily be AAA.

In the case of a covered bond issued in domestic currency, at the three largest rating agencies, this latter rating requires at least rating $\mathrm{A}$ - from the country where the bank's seat is located. Out of the four large covered bond-issuing countries in Table 1, Spain has the poorest rating. From the three large rating agencies, Spain received the following ratings ${ }^{14}$ : S\&P "A" outlook: negative; Fitch "A-" outlook stable; Moody's "Baa1" outlook stable. Regarding the three large rating agencies, Spain is 5 notches below AAA rating at S\&P, 6 notches below AAA rating at Fitch, while 7 notches below AAA rating at Moody's. Namely, if other considerations allow, currently, the upper limit of the rating of Spanish covered bonds is not the highest (Aaa) but less by one notch (Aa1) only at Moody's due to the country ceiling.

As far as covered bonds are concerned, the outstanding ratings are backed by very good experience from the past. According to the analysis by Moody's encompassing more than two decades between 1997 and 2019 (Moody's Investor Service, 2020a), 33 out of the covered bond issuers rated by them went bankrupt, but the holders of covered bonds did never suffer any losses, while in four out of 33 cases

12 Overcollateralization indicates to what extent the bond portfolio's underlying cover pool exceeds the stock of bonds. Overcollateralization is determined in proportion to the bonds (the bank's portfolio of assets). Overcollateralization increases the expected return on a bond unit.

13 The annex shows how the rating scales of the five credit rating agencies match.

14 As of 20 March 2021. 
(two Greek banks and a Cyprian bank), depositors suffered losses, as well. In the four latter cases, holders of uncovered bonds issued by the banks (both senior and junior bonds) suffered losses, as well. In the case of further three banks, depositors did not suffer any losses, but senior bondholders from the holders of uncovered bonds did. Holders of junior bonds could avoid losses only in four cases. In view of the above, looking back, it can be stated that covered bonds were less risky indeed than the uncovered bonds issued by the same banks. At the same time, based on positive experience from the past, we cannot make any sound judgements about the future.

\subsection{The methodology of individual credit rating agencies}

Diagram 1 illustrates the market shares of the five credit rating agencies each of which has a market share of more than $1 \%$ in the market of the rating of structured products. The following part of our article presents their rating practices in descending order of their market share.

\section{Diagram 1}

\section{The share of credit rating agencie}

in the rating of structured products $(2020, \%)$

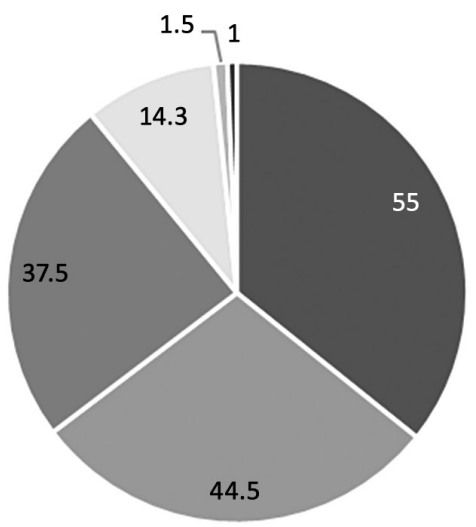

Moody's Fitch $\square$ S\&P DBRS Scope $\square$ Other

Note: The amount of percentages may exceed 100, as several structured products are rated by more than one credit rating agency.

Source: ESMA (2020) 


\subsubsection{Moody's ${ }^{15}$}

The starting point of Moody's covered bond rating model is a two-stage expected loss model (EL model). In the framework of this, firstly, it is determined how probable it is that the issuer will stop payments related to covered bonds. Secondly, the amount of loss in the event of the occurrence of the first case is estimated. Then the rating is fine-tuned by means of the so-called TPI indicator.

As a starting point, in the framework of the expected loss model, according to Moody's definition, the probability of the suspension of the payment of covered bonds is an event rated by one notch higher than the issuer. The reason for this is that they take into account that, pursuant to the European rules on the resolution of banks, covered bonds cannot be involved into a possible bail-in. If payments are suspended, the loss is determined by the value of the collaterals. When assessing collaterals, EL models take three factors into account: the quality of collaterals (including expected decrease in loss due to overcollateralization), the risk of the refinancing of the collaterals and the degree of interest rate risk and foreign exchange rate risk arising from interest and currency differences between the underlying assets and the bonds financing them. Depending on the results of EL models, the rating can be improved by further 2-5 notches.

In the framework of modelling the TPI indicator (timely payment indicator), Moody's determines the probability of whether payments to bondholders will continue in an unchanged manner, according to the original schedule if the issuing bank goes bankrupt. The 6 categories according to the TPI are the following: "highly unlikely", "unlikely", "possible”, "highly possible”, "high”, "very high”. The most important element of the TPI is refinancing risk, i.e. the risk that the underlying assets of covered bonds may lose their liquidity due to market problems. In addition, Moody's examines the legal environment, possible support that can be expected from the public or private sector, the existing coverage agreements, the type of underlying collaterals (e.g. coverage with state guarantee) and other arising factors. The TPI can improve the ratings based on the EL model by maximum 4 additional notches.

The rating modified by the TPI indicator can be higher by maximum 10 notches than the rating of the issuing bank. Consequently, in the case of a "very high" TPI classification, even a covered bond issued by a bank with Baaz rating, i.e. belonging to the lowest level of the investment grade category, may receive Aaa rating, the best rating given by Moody's.

15 The description is based on: Moody's Investor Service (2020/b and 2020/c) 
The aforementioned values may be decreased by country ceilings which cannot be exceeded by any covered bond rating. In the case of bonds issued in domestic currency, this value can be higher by no more than 6 notches than the sovereign rating of Treasury bonds issued in domestic currency. In the case of covered bonds issued in foreign currency, the country ceiling tends to be lower by 0-3 notches than country ceiling determined in domestic currency.

\subsubsection{Fitch $^{16}$}

At Fitch, the starting point for the rating of covered bonds is the rating of the issuing bank, which can be increased by one or two notches by the possibility of extraction from bail-in. Just like in the case of Moody's, they also continue by analysing the effect of the payment continuity on the rating of the covered bond if the issuer stops the payment of the receivables embodied by the bonds. Fitch calls it PCU (Payment Continuity Uplift). When calibrating extra notches which can be given in the framework of the PCU, Fitch examines how effective liquidity protection existing in the covered bond facility is. Liquidity protection can be prescribed by the law or guaranteed by contract. The highest raise (by eight notches) can be given if the duration of liquidity protection exceeds the maturity of the element of the covered bond portfolio with the longest maturity. Lower raise (by six, five, four or three notches) can be given depending on how many months the liquidity support lasts, whether the portfolio that serves as collateral consists of mortgage loans, loans granted to the public sector or the combination of these and whether the collaterals comprise loans granted in developed or developing banking markets. Upgrading in the framework of the PCU may be lower at such values if certain risks can undermine payment continuity, for example when the covered assets are not appropriately separated in the books of the issuing bank.

Fitch has another possibility to raise the covered bond's rating compared to the bank's rating if the bondholders can expect considerable return (higher than half of the nominal value of the bond) from the underlying collateral of the loan package constituting the bonds, when the issuer stops the payment of the bonds. In such cases, the classification of the expected return may be good, very good or excellent. Accordingly, the rating can be improved by 1-3 notches.

In Fitch's rating process, following the consideration of the factors which could improve the rating, it is analysed how high the overcollateralization should be, so that, even in the case of a stress scenario, the cash flow from the loan portfolio can cover the payment obligations towards the bondholders and upgrading by 1-3

16 The description is based on: Fitch Ratings (2020a; 2020b). 
notches owing to the return from the portfolio of underlying assets can be realistic even in the case of a stress scenario. For each rating category, based on the rating of the issuer, Fitch determines the expected degree of overcollateralization needed for the actual application of upgrading notches. If overcollateralization fails to reach this degree, Fitch may decrease total notch raises, which are otherwise deserved based on the methodology, by one notch.

All in all, according to Fitch, the rating can be improved by maximum 13 notches, therefore even a covered bond issued by an issuer with a highly speculative B+ rating may get AAA rating if the relevant requirements are met.

At Fitch, country risk, as the ceiling of upgrading, is also part of the methodology. Consequently, upgrading by maximum 13 notches can only be taken advantage of within the country ceiling. In the case of covered bonds denominated in the domestic currency, the country ceiling can be the rating of sovereign bonds issued in the domestic currency plus maximum six notches. In the case of covered bonds denominated in foreign currency, the rating of the bonds cannot exceed the rating of Treasury bonds unless the related convertibility and transfer risks have not been demonstrably reduced. In the latter case, the rating of covered bonds denominated in foreign currency can be higher by maximum 4 notches than that of sovereign bonds which are also denominated in foreign currency.

\subsubsection{Standard and Poor (S\&P) ${ }^{17}$}

At $S \& P$, the rating of covered bonds is also based on the rating of the issuing bank. The next step is to determine the factors which may improve the rating of the covered bond compared to the rating of the issuer. At S\&P, the first improving factor is also the fact that the covered bonds cannot be involved in bail-in. As a result of this, the bond can be upgraded by one or two notches. After that the maximum possible rating of the covered bonds is determined, based on the factors which may improve the rating. These factors can be classified into two groups. The first group includes subsidies based on legislation. Such subsidies can be poor, moderate, strong or very strong. Depending on these categories, one, two or three notches can be added to the rating. The second group includes market opportunities based on the collateral, which may ensure that bondholders get the amounts they are entitled to in an unchanged manner if the issuer stops the payments of the bond. In the framework of this, the quality of the loan portfolio providing the underlying assets of the bond (credit risk) and the risks of the refinancing of the portfolio are analysed. In relation to the latter, it can be stated that the more liquid

17 The description is based on: S\&P Global Ratings (2015) and S\&P Global Ratings (2019). 
the secondary market, where resources for the refinancing of the bonds can be obtained, is, the higher the chance of upgrading is. The two factors together can increase the level of rating following subsidies based on legislation by maximum 4 notches. If the bonds do not have any underlying liquidity support system that can ensure the payment of the bonds for at least six months if the issuer stops payments, or, if the expected overcollateralization does not exist in the case of the covered bonds, S\&P decreases the rating by one notch respectively.

The rating calculated in the aforementioned manner can exceed the rating of the issuing bank by maximum 9 notches. In view of this, the issuer with the worst rating whose covered bond can still get an AAA rating belongs to the lowest investment grade category (BBB-). The covered bond's rating cannot be upgraded to $\mathrm{AAA}$ if the issuer has speculative rating (BB+ or below).

At S\&P, the country ceiling is not separated on the basis of issuance in the domestic currency or foreign currency, but based on whether the issuer and the cover pool representing the covered bonds are in the same country. In this case, country ceiling can be maximum six notches higher than the rating of sovereign bonds. If the issuer and the cover pool are in different countries, S\&P can improve the rating of covered bonds by maximum six notches if the countries' sovereign ratings are B (highly speculative category) or better. If the countries have worse sovereign ratings, the bonds can be upgraded to maximum $\mathrm{BB}$.

\subsubsection{DBRS ${ }^{18}$}

The rating system of DBRS consists of four steps. Firstly, they define the starting point of rating. It can be two notches higher than the rating of the issuing bank, due to preferential treatment in the resolution process. Secondly, they decide on by how many notches the rating can be improved compared to the result after the first step, depending on legal and structural factors. The likelier it is that the payments related to the covered bond will continue under the original terms in the event of bankruptcy of the issuing bank, the greater the upward divergences can be. This analysis requires a primarily legal approach, in the course of which DBRS takes into account three factors. These factors are the following:

1) how feasible the actual separation of the covered bond portfolio is for the sake of the bondholders,

2) whether the cash flow deriving from the covered bond portfolio in due time, based on the legal environment as well as structural factors,

18 The description is based on: DBRS (2020). 
3) whether there is a business continuity plan and related supervisory support to ensure the continuous payment of covered bonds in the event of the bankruptcy of the issuing bank.

Based on this step, the issued covered bonds were divided into five categories.

The legal and structural framework can be poor, average, appropriate, strong or very strong. In the case of 'very strong' classification, the rating can be improved by maximum 6 notches. Thirdly, the cover pool of the bonds is rated. This rating methodology is based on the estimate of the probability of default and, that of the level of loss given default. This is also complemented by the estimation of cash flow from the assets along a stress scenario. At this point, the overcollateralization of the portfolio is considered, as well. After this step, the matrices of DBRS's covered bond ratings are prepared. One matrix is created for each of the five categories of legal and structural classification defined at the second stage. The two dimensions of this matrix are the initial ratings determined at the first stage and the cover pool ratings determined at the third stage. As far as the matrix belonging to the very strong legal and structural framework is concerned, the covered bond can receive AAA rating if the rating of the cover pool is AAA, but if the initial rating is $\mathrm{A}$ (low), i.e. six notches lower than AAA, and the rating of the issuing bank is lower by further two notches (BBB). In the case of the matrix belonging to the poorest legal and structural framework, covered bonds with AAA rating can only belong to AAA and AA (high) initial rating categories (an issuer with at least AA (low) classification). At the fourth stage, if DBRS believes that the covered bond portfolio may provide considerable support in the event of the default of the covered bond, ratings in the matrices creates at the third stage can be improved by further 2 notches.

Concerning bonds collateralized by mortgages, the methodology of DBRS does not include a country ceiling, however, they take into account the effect of possible increase in sovereign risk when taking several steps. If the bonds are covered by loans granted to the public sector, their ratings can exceed the sovereign rating of the home country of the issuing bank by maximum 3 notches.

\subsubsection{Scope ${ }^{19}$}

At Scope, the starting point for the rating of covered bonds is also the rating of the issuing bank. However, initially, they do not raise this due to the lack of involvement into bail-in, but rather assess it as a part of the legal framework. Concerning modifications, the first step of Scope is the assessment of those fundamental

19 The description is based on: Scope (2020) 
support systems due to which covered bonds can continuously perform payments even if the issuing bank become insolvent. At this stage, Scope analyses two factors: the rules of bank resolution and the legal framework system applying to covered bonds. Here, the assessment of the resolution rules also includes the assessment of the possibility of extraction from bail-in. In addition, all aspects which support the preferential treatment of a given covered bond by the regulators in the event of bankruptcy are evaluated. Such aspects may include, e.g. the systemic importance of the covered bonds in the given country. In total, due to the character of the resolution system supporting covered bonds, 4 additional notches can be given. The legal framework does not take into account the payment-supporting instruments which exist at the stage of resolution, but rather those which do not operate in a period of established insolvency, but prior to or after that period instead. In this way, rating can be improved by additional two notches. In other words, the payment-supporting character of the resolution and legal framework can result in a maximum six-notch higher rating than that of the issuing bank.

The next step is the assessment of the quality of the cover pool. In the course of analysing this, Scope examines the following three factors:

1) the assessment of the underlying assets and that of the cash flows deriving from them by using the expected loss model,

2) the quality of the issuer's risk management and

3) the degree of overcollateralization.

At this stage, rating can be improved by further three notches. At Scope, there is no country ceiling regarding to what extent the rating of the covered bond can exceed the sovereign rating.

Another characteristic of Scope's methodology is that the cover pool analysis conducted at stage two is considered to be an important factor in terms of the rating if the rating of the covered bond with the extra notches given in the analysis at the first stage (resolution and legal framework) has not reached AAA level yet. If it has reached AAA level, the quality of the cover pool does not play a key role in rating anymore, and it is considered to be important only in terms of the probability of the stability of the rating. In this case, the analysis of the cover pool is not complete. 


\section{THE COMPARISON OF THE METHODOLOGIES USED BY THE FIVE CREDIT RATING AGENCIES}

Regarding all the five credit rating agencies, it can be established that the rating of covered bonds can typically exceed by several categories both the rating of the issuing bank and the sovereign rating of the home country of the bank. Table 3 contains the composition and degree of the possible extra notches which can be added to the rating of the issuing bank. The cells of the table which represent the first step within the given rating system following the determination of the initial rating are highlighted with black.

Among credit rating agencies, the greatest improvement of the issuer's rating (by 13 notches) can be achieved at Fitch, while other credit rating agencies allow improvement of 9-10 notches. At each rating agency, the top of the speculative rating category is 10 notches from the AAA rating, therefore even bonds issued by banks with not too good ratings can get into the (practically risk-free) categories of AAA or AA. It is also proven by the fact that according to the benchmark calculations prepared by the ECB for its covered bond purchases, at the end of 2018, 76.5\% of the covered bonds issued in the Eurozone were rated AAA, 20.4\% were rated AA, 2.7\% were rated A and merely $0.3 \%$ belonged to the BBB category (ECB, 2019:79).

Lines 6 and 7 of Table 3 show the relationship between the country ceilings related to covered bonds and the rating of sovereign bonds of the home country at the given credit rating agency. In other words, how the country ceilings can limit the possibility to give all the extra notches based on the rating to a given covered bond. As we see, not really. 
Table 3

Maximum improvement units (notches) which can be given beyond the rating of the issuing bank

\begin{tabular}{|c|c|c|c|c|c|c|}
\hline & & Moody's & Fitch & S\&P & DRBS & Scope \\
\hline 1 & $\begin{array}{l}\text { Initial rating owing to the } \\
\text { lack of the possibility of } \\
\text { involvement into bail-in }\end{array}$ & 1 & 2 & 2 & 2 & $\begin{array}{l}0 \text { (it is considered } \\
\text { related to the legal } \\
\text { framework) }\end{array}$ \\
\hline 2 & $\begin{array}{l}\text { Legal and structural } \\
\text { framework }\end{array}$ & 4 & & 3 & 6 & 6 \\
\hline 3 & $\begin{array}{l}\text { Assessment of the cover } \\
\text { pool }\end{array}$ & 5 & 3 & 4 & 2 & 3 \\
\hline 4 & Liquidity protection & & 8 & & & \\
\hline 5 & $\begin{array}{l}\text { IN TOTAL - maximum } \\
\text { possible diversion }\end{array}$ & 10 & 13 & 9 & 10 & 9 \\
\hline 6 & $\begin{array}{l}\text { Country ceilings beyond } \\
\text { sovereign classification } \\
\text { (bonds denominated in } \\
\text { the domestic currency) }\end{array}$ & 6 & 6 & 6 & $\begin{array}{l}\text { in the case of } \\
\text { mortgage-covered } \\
\text { bonds, it is not } \\
\text { determined; if the } \\
\text { collateral is a loan } \\
\text { granted to the public } \\
\text { sector: } 3\end{array}$ & none \\
\hline 7 & $\begin{array}{l}\text { Country ceilings beyond } \\
\text { sovereign classification } \\
\text { (bonds denominated in } \\
\text { foreign currency) }\end{array}$ & 6 & 4 & 6 & $\begin{array}{l}\text { in the case of } \\
\text { mortgage-covered } \\
\text { bonds, it is not } \\
\text { determined; if the } \\
\text { collateral is a loan } \\
\text { granted to the public } \\
\text { sector: } 3\end{array}$ & none \\
\hline
\end{tabular}

Source: own compilation

On the whole, as Table 3 shows, in the case of all five rating agencies, the legal and regulatory environment (including rules on bank resolution) plays a more important role in the methodology of the rating of covered bonds than the quality of the cover pool itself. At S\&P, DRBS and Scope, the fundamental starting point for ratings is the legal protection of covered bonds. Even the liquidity protection, primarily analysed by Fitch, rather focuses on the protection backed by laws and contracts instead of factors arising from risk management and the quality of the portfolio. Only Moody's methodology is based on reverse logic: the analysis of the quality of the cover pool is carried out prior to the assessment of the legal and structural framework. The secondary character of the quality analysis of the portfolio is the most pronounced in case of Scope, where if the rating has improved to AAA due to the legal environment, they do not even conduct a comprehensive analysis of the cover pool, therefore the size of the rating buffer (the number of unused notches) is unknown. 


\section{CONCLUSIONS}

The article introduced, analysed and compared the covered bond rating practices of credit rating agencies. We pointed out that, due to the methodology applied by credit rating agencies, covered bonds are bonds with outstanding rating. Their rating can even be significantly better than that of the issuing bank or that of the home country of the issuing bank. Owing to their legal construction, covered bonds carry lower risks indeed than the uncovered bonds of the issuing bank, as, in the event of the bankruptcy of the issuing bank, there are several lines of defence to reduce the risks of bondholders. Another fact is that during the global financial crisis of 2008 and the ensuing crisis of the Eurozone, there were no crashes in the market of covered bonds, while a large number of CDOs were affected by devaluation. Although several banks were granted a state bail-out package, therefore the owners of banking liabilities (not only the holders of covered bonds) did not suffer any losses in many cases. At the same time, the fact that more than 99\% of covered bonds have at least A rating and 3/4 of them have AAA rating in the Eurozone creates the illusion that covered bonds are practically risk-free instruments and are less risky than government securities in the case of countries which do not have AAA rating. The introduced methodology of the rating agencies also suggests that many covered bonds could belong to the "better than the best" category if such a term existed, as they often need less than the maximum number of possible extra notches to reach the AAA category.

At the same time, covered bonds are obviously not risk-free products. They are sensitive to the decrease in real estate prices and crashes in the real estate market. Following the 2008 global economic crisis, in many European countries, there was serious recession in the real estate market, and also several bank failures. Nevertheless, due to the aforementioned state bail-out packages, it did not turn out whether covered bonds could have continued payment to bondholders even under the circumstances of a sovereign and/or banking crisis. Consequently, it has never been tested whether the rating of covered bonds can be so definitely separated from bank and sovereign ratings, as, in the event of a contingent sovereign bankruptcy, the strength of protection laid down in regulation and legal guarantees can be seriously questioned, as well.

Since the 2008 crisis, the judgement of the rating practice of covered bonds has been made more difficult by the fact that, regarding their excellent ratings, central banks (the ECB in the Eurozone) have become the main buyers of covered bonds, which provides automatic (but not long-term) market protection to this market segment. The favourable market situation maintained by the ECB also contributes to the fact that covered bonds are extremely good investment instruments. Even 
if it is formally not part of the rating methodology, it implicitly contributes to the sustainability of excellent ratings.

The main conclusion of the article is that the methodology applied by credit rating agencies to rate covered bonds can easily result in excellent ratings, which are not really limited by the ratings of either the issuing bank or the home country. When determining the ratings, extra protection deriving from the regulatory environment plays a key role. In general, this protection works well, but the question is whether it would work even in the event of a serious market crash.

\section{ANNEX}

The comparison of the rating scales of the five credit rating agencies involved in the analysis

\begin{tabular}{|c|c|c|c|c|c|}
\hline & Moody's & $\mathrm{S} \& \mathrm{P}$ & Fitch & DBRS & Scope \\
\hline \multirow{10}{*}{$\begin{array}{l}\text { Investment } \\
\text { category }\end{array}$} & Aaa & AAA & AAA & AAA & AAA \\
\hline & Aa1 & $\mathrm{AA}+$ & $\mathrm{AA}+$ & AA (high) & $\mathrm{AA}+$ \\
\hline & $\mathrm{Aa} 2$ & AA & AA & AA & $\mathrm{AA}$ \\
\hline & Aa3 & AA- & AA- & AA (low) & AA- \\
\hline & $\mathrm{A} 1$ & $\mathrm{~A}+$ & $\mathrm{A}+$ & A (high) & $\mathrm{A}+$ \\
\hline & $\mathrm{A} 2$ & $\mathrm{~A}$ & A & A & A \\
\hline & A3 & A- & A- & A (low) & A- \\
\hline & Baal & $\mathrm{BBB}+$ & $\mathrm{BBB}+$ & BBB (high) & $\mathrm{BBB}+$ \\
\hline & Baa2 & BBB & $\mathrm{BBB}$ & $\mathrm{BBB}$ & $\mathrm{BBB}$ \\
\hline & Baa3 & BBB- & BBB- & BBB (low) & BBB- \\
\hline \multirow[t]{11}{*}{$\begin{array}{l}\text { Speculative } \\
\text { category (junk) }\end{array}$} & $\mathrm{Ba} 1$ & $\mathrm{BB}+$ & $\mathrm{BB}+$ & BB (high) & $\mathrm{BB}+$ \\
\hline & $\mathrm{Ba} 2$ & $\mathrm{BB}$ & $\mathrm{BB}$ & $\mathrm{BB}$ & $\mathrm{BB}$ \\
\hline & $\mathrm{Ba} 3$ & BB- & BB- & BB (low) & BB- \\
\hline & $\mathrm{B} 1$ & $\mathrm{~B}+$ & $\mathrm{B}+$ & B (high) & $\mathrm{B}+$ \\
\hline & B2 & B & $\mathrm{B}$ & B & B \\
\hline & B3 & B- & B- & B (low) & B- \\
\hline & Caal & $\mathrm{CCC}+$ & CCC & CCC (high) & $\mathrm{CCC}$ \\
\hline & $\mathrm{Caa} 2$ & CCC & & CCC & $\mathrm{CC}$ \\
\hline & $\mathrm{Caa} 3$ & CCC- & & CCC (low) & $\mathrm{C}$ \\
\hline & $\mathrm{Ca}$ & $\mathrm{CC}$ & $\mathrm{CC}$ & CC (high) & \\
\hline & & $\mathrm{C}$ & $\mathrm{C}$ & $\mathrm{CC}$ & \\
\hline Insolvent & $\mathrm{C}$ & $\mathrm{D}$ & $\mathrm{D}$ & $\mathrm{C}$ & $\mathrm{D}$ \\
\hline
\end{tabular}




\section{REFERENCES}

DBRS (2020): Methodology - Rating and Monotoring Covered Bonds. April, https://www.dbrsmorningstar.com/research/360260/rating-and-monitoring-covered-bonds.

EBA (2014): EBA report on covered bond frameworks and capital treatment. https://www.eba. europa.eu/sites/default/documents/files/documents/1018o/534414/fa5bf6ec-6301-4b9o-8f983324333 c82a4/EBA\%2oReport\%2oon\%20EU\%2oCovered\%2oBond\%2oFrameworks\%2oand\%20 Capital\%2oTreatment.pdf?retry=1.

EBA (2016): EBA Report on Covered Bonds. EBA-OP-2016-23. https://www.eba.europa.eu/sites/ default/documents/files/documents/1018o/1699643/d2bo8b75-601f-4de3-ba36-ad674cdcod46/ EBA\%2oReport\%20on\%2oCovered\%2oBonds\%20\%28EBA-Op-2016-23\%29.pdf?retry=1.

EC (2015): Action Plan Building a Capital Markets Union, COM(2015) 468 final. https://ec.europa.eu/ transparency/regdoc/rep/1/2015/EN/1-2015-468-EN-F1-1.PDF.

ECB (2019): Economic Bulletin, Issue 2. https://www.ecb.europa.eu/pub/pdf/ecbu/ eb201902 a070c3a338.en.pdf.

ECBC (2020): European Covered Bond Fact Book 2020. https://hypo.org/ecbc/publications/factbook/.

ESMA (2020): Report on CRA Maket Share Calculation. ESMA 33-9-32, 14 December, https:// www.esma.europa.eu/sites/default/files/library/esma_33-9-383_cra_market_share_calculation_2020_o.pdf.

Fitch Ratings (2020a): Covered Bonds Rating Criteria. 18 November, https://www.fitchratings.com/ research/structured-finance/covered-bonds/covered-bonds-rating-criteria-18-11-2020.

Fitch Rating (2020b): Structured Finance and Covered Bonds Country Risk Rating Criteria. 23. September, https://www.fitchratings.com/research/structured-finance/structured-finance-covered-bonds-country-risk-rating-criteria-23-09-2020.

Gaillard, N. (2013): What is the Value of Sovereign Ratings? German Economic Review, 15(1), 208224.

Kemmish, R. - Wilkinson, C. - Andruszkiewicz, O. (2017): Covered Bonds in the European Union: Harmonisation of legal frameworks and market behaviours. Final report, European Commission.

Moody's Investor Service (2020a): Rating transition rates for covered bond deals, 1997-2019. https:// www.moodys.com/researchdocumentcontentpage.aspx?docid=PBS_1117861.

Moody's Investor Service (2020b): Rating methodology - Moodys's Approach to Rating Covered Bonds. October 26, https://www.moodys.com/research/Moodys-updates-its-methodology-forrating-covered-bonds--PBS_1248889.

Moody's Investor Service (2020c): Country Ceilings Methodology. December 7, https://www.moodys.com/researchdocumentcontentpage.aspx?docid=PBC_1225594.

Mullard, M. (2012): The Credit Rating Agencies and Their Contribution to the Financial Crisis. The Political Quarterly, 83(1), 77-95.

S\&P Global Ratings (2015): Covered Bonds: Covered Bond Rating Frameworks: Methodology and Assumptions. https://www.standardandpoors.com/en_US/web/guest/ratings/ratings-criteria/-/articles/criteria/structured-finance/filter/covered-bonds.

S\&P Global Ratings (2019): Incorporating Sovereign Risk in Rating Structured Finance Securities: Methodology and Assumptions. https://www.standardandpoors.com/en_US/web/guest/ratings/ratings-criteria/-/articles/criteria/structured-finance/filter/general.

Scalet, S. - Kelly, T. F. (2012): The Etics of Credit Rating Agencies: What Happened and the way Forward. Journal of Business Ethics, 111, 477-490. 
STÖCKER, O. (2020): Overview of covered bonds. In ECBC (2020), 143-150.

STÖcker, O. (2021) EU harmonisation of covered bonds. Essay. Economy and Finance, 8(1), $27-56$. https://bankszovetseg.hu/Public/gep/2021/027-056_E_StockerO.pdf.

White, L. J. (2009): The credit rating agencies and the subprime debacle. Critical Review 21(2-3), 389-399. 